\title{
COULD THE R-RATIO BE AN INDICATOR OF ACUTE LIVER INJURY FOR THE TREATMENT OF COVID-19?
}

\author{
R-ORANI, COVID-19 TEDAVISINDE AKUT KARACIĞER HASARININ BIR GÖSTERGESi \\ OLABILIR MI?
}

\author{
Yıldırım KAYACAN' (D, Hayrullah YAZAR² (D), Mehmet ÖZDiN (D) \\ ${ }^{1}$ Ondokuz Mayıs University, Yasar Dogu Faculty of Sports Sciences, Samsun, Turkey \\ ${ }^{2}$ Sakarya University, Faculty of Medicine, Department of Medical Biochemistry, Sakarya, Turkey \\ ${ }^{3}$ Sakarya Training and Research Hospital, Sakarya, Turkey
}

ORCID IDs of the authors: H.Y. 0000-0001-9447-6322; Y.K. 0000-0003-2784-2980; M.Ö. 0000-0003-3077-7171

Cite this article as: Kayacan Y, Yazar H, Ozdin M. Could the R-ratio be an indicator of acute liver injury for the treatment of COVID-19. J Ist Faculty Med 2021;84(3):311-7. doi: 10.26650/IUITFD.2021.824074

\section{ABSTRACT}

Objective: The aim of the study was to determine whether the R-ratio could be an indicator in COVID-19 patients.

Material and Method: Alkaline phosphatase (ALP) and alanine aminotransferase (ALT) were measured in the first blood serum of all patients $(n=314)$, and R-values were determined and grouped. Then, the correlations between the detected parameters were examined and the differences were analyzed by gender. Patients were compared according to the ALT and ALP upper values of the reference interval. Alpha value was accepted as $<0.05$.

Results: In all patients, ALT and ALP were detected well above normal reference ranges $(p=0.000)$. The $R$-value ratio was significantly associated with ALT and ALP ( $p<0.001)$. R-groups were statistically significant and inversely proportional to age $(p=0.049)$. It was detected that the R-ratio of $\geq 5$ was higher in women than in men.

Conclusion: According to our findings, ALT and ALP measurements in patients diagnosed with COVID-19 were much higher than normal. Another interesting result of our research was that the R-ratio was found to be $\leq 2$ in the majority of our patients. The $\mathrm{R} \leq 2$ finding, which is accepted as an indicator of acute liver injury, suggested that tracking of this value for COVID-19 could be an important indicator.

Keywords: SARS-CoV-2, COVID-19, R-Ratio, ALT, ALP

\section{ÖZET}

Amaç: Çalışmanın amacı, COVID-19 hastalarında R oranının bir gösterge olup olamayacağını belirlemektir.

Gereç ve Yöntem: Tüm hastaların ( $n=314)$ ilk kan serumunda alkalen fosfataz (ALP) ve alanin aminotransferaz (ALT) ölçülerek $R$ değerleri belirlendi ve gruplandı. Daha sonra tespit edilen parametreler arasındaki korelasyonlar incelenerek ve farklılıklar cinsiyete göre analiz edildi. Ayrıca hastalar referans aralığın ALT ve ALP üst değerlerine göre karşılaştırıldı. Alfa değeri <0,05 olarak kabul edildi.

Bulgular: Tüm hastalarda, ALT ve ALP normal referans aralıklarının oldukça üzerinde tespit edildi $(p=0,000)$. R-değeri oranı, ALT ve ALP ile önemli ölçüde ilişkiliydi $(p<0,001)$. $R$ grupları istatistiksel olarak anlamlı ve yaşla ters orantılıydı $(p=0,049)$. Kadınlarda $\geq 5$ R oranının erkeklere göre daha yüksek olduğu tespit edildi.

Sonuç: Bulgularımıza göre COVID-19 tanısı alan hastalarda ölçülen ALT ve ALP normalden çok daha yüksekti. Araştırmamızın bir başka ilginç sonucu da hastalarımızın çoğunda R-oranının $\leq 2$ olarak bulunmasıydı. Akut karaciğer hasarının bir göstergesi olarak kabul edilen R $\leq 2$ bulgusu, COVID-19 için bu değerin izlenmesinin önemli bir gösterge olabileceğini düşündürmektedir.

Anahtar Kelimeler: SARS-CoV-2, COVID-19, R-Oranı, ALT, ALP

Corresponding author/iletişim kurulacak yazar: kayacan@gmail.com

Submitted/Başvuru: 10.11.2020 • Revision Requested/Revizyon Talebi: 19.01.2021 •

Last Revision Received/Son Revizyon: 20.01.2021 • Accepted/Kabul: 17.02.2021 • Published Online/Online Yayın: 02.07.2021 


\section{INTRODUCTION}

Various treatment trials are rapidly progressing in COVID-19 patients. Furthermore, searches for biomarkers continue. Alanine aminotransferase (ALT) and alkaline phosphatase (ALP) remain at the forefront for the examination of liver functions among the test parameters that are followed both for revealing the effects of the disease and the drugs used.

As far as is known, ALT is an aminotransferase consisting of an enzyme group that catalyzes the conversion of $\alpha$-keto acids into amino acids by transferring amino groups (1). ALT is located in the cytosol of hepatocytes, and high serum levels indicate a disruption in the integrity of the hepatocyte plasma membrane. ALT has a higher diagnostic sensitivity in terms of liver-biliary disease compared to AST (2). This sensitivity made ALT stand out as a test to be examined in the COVID-19 pandemic because ALT's specific activity in the liver is about 10 times higher than in heart and skeletal muscle, and high serum ALT activity is mainly accepted as an indicator of parenchymal liver disease (3).

Although the exact metabolic function of ALP, which is another test parameter discussed in our study, has not been fully explained yet, this parameter has been associated with intestinal lipid absorption and bone calcification (4). It may also be high in secondary bone diseases such as skeletal metastases and in diseases such as multiple myeloma, acromegaly, kidney failure, hyperthyroidism, ectopic ossification, sarcoidosis, bone tuberculosis, and fracture healing (5). The Biliary epithelium is the main source of alkaline phosphatase (ALP), which increases in liver damage. The causes of intra-extrahepatic cholestasis, resulting in biliary epithelial damage, produce an increase in serum ALP levels (3). There have been many studies on ALP, which are also discussed in the COVID-19 pandemic (6-8). The examination of ALP in many diseases can be associated with the fact that it is found especially in cell membranes or inside the cell, and is seen in almost all body tissues. This is probably the reason why it is the second preferred test parameter next to ALT for calculating the R-value.

The "R-value" is very useful and beneficial for distinguishing acute liver damage. This value was formed by the Council for International Organizations of Medical Sciences of the World Health Organization (WHO) for the differentiation of drug-induced types of acute liver injury (9). The R-value is found by proportioning the ratio of the ALT and ALP values, which are measured in the patient, to the upper limit of normal (ULN). If the R-value is $\geq 5$, it can be said that hepatocellular damage occurs. If the R-value is $\leq 2$, sepsis, choledocholithiasis and heart failure ocur, and if the R-value is between $2-5$, it can be interpreted as mixed type damage $(10,11)$. In our study, we investigated whether COVID-19, which is caused by the newly emerged SARS-CoV-2 virus, leads to acute liver damage by using the R-ratio. This ratio is a value used by the Council for International Organizations of Medical Sciences of the World Health Organization to differentiate the drug-induced types of acute liver injury. We hope that our research will shed light on some unknown points for the clinical course of COVID-19, especially about the liver, since our research is not yet found in the literature.

\section{MATERIAL AND METHOD}

The study was conducted on patients diagnosed with COVID-19 $(n=314)$ between 15 March 2020 and 9 April 2020, by Ondokuz Mayıs University, Faculty of Medicine. The patients examined in the study consisted, of people, who had not previously used any medication nor had been treated for any kind of liver disease ALT and ALP values taken from the first blood serum of the patients were obtained by scanning through the Hospital Information Management System (HIMS). Then, the R-values of the patients during the first admission were calculated according to the formula " $R=(A L T \div$ upper limit of normal for $A L T)$ / (ALP - upper limit of normal for ALP)" defined by the $\mathrm{WHO}$. The calculated values were grouped according to the reference intervals specified in the literature (R-value $\geq 5, R \leq 2, R=2-5)(10,11)$.

Age and gender were also considered in patients diagnosed with COVID-19 via real-time polymerase chain reaction (RT-PCR) and computed tomography (CT) lung screening. All patient blood samples were taken from the venous blood by phlebotomists. Cooled centrifugation was performed at $5000 \mathrm{rpm}$ for 10 minutes to obtain serum. Ethical approval of the study was given by the Sakarya Medical School Ethics Committee (Date: 13.04.2020, No: 147).

\section{Performance characteristics of biochemical tests}

The ALT and ALP test parameters were analyzed in blood serum on a Beckman Coulter brand AU 5800 (serial no: 2016022598, Koutou-ku, Tokyo, Made in Japan) fully automatic autoanalyzer, using the photometric method.

\section{ALT methodology}

This ALT procedure is based on principles outlined by Wroblewski and LaDue (12) and utilizes a modification of the methodology recommended by the International Federation of Clinical Chemistry (IFCC) (13). ALT transfers the amino group from alanine to $\alpha$-oxoglutarate to form pyruvate and glutamate. The pyruvate enters a lactate dehydrogenase (LD) catalyzed reaction with $\mathrm{NADH}$ to produce lactate and NAD+. The decrease in absorbance due to the consumption of NADH is measured at $340 \mathrm{~nm}$ and is proportional to the ALT activity in the sample.

\section{ALP methodology}

This ALP procedure is based on the method developed by Bowers and McComb and has been formulated as recommended by the AACC and IFCC $(14,15)$. Alkaline phos- 
phatase activity is determined by measuring the rate of conversion of $\mathrm{p}$-nitrophenyl phosphate (pNPP) in the presence of 2-amino-2-methyl-1-propanol (AMP) at pH 10.4. The rate of change in absorbance due to the formation of PNP is measured bi-chromatically at 410/480 nm and is directly proportional to the ALP activity in the sample.

\section{ALT (normal value: 0-35 U/L)}

Linearity: The test is linear in the range of 3-500 U/L enzyme activity.

Sensitivity: The lowest detectable level represents the lowest measurable ALT level unlike zero and is estimated at $1 \mathrm{U} / \mathrm{L}$.

Precision: The total CV value was determined to be 0.80 .

\section{ALP (normal value: $30-120 \mathrm{U} / \mathrm{L}$ )}

Linearity: the test is linear in the range of 5-1500 U/L enzyme activity.

Sensitivity: The lowest detectable level was estimated at $1 \mathrm{U} / \mathrm{L}$.

Accuracy: The total \% CV value was determined as 2.15 .

\section{Statistics}

Statistical analysis was performed using SPSS v.21(IBM, Armonk, NY, USA). The patient findings did not show normal distribution (Shapiro-Wilk, $p=0.000$ ) which is why Spearman's rho was used for correlation analyses while Mann-Whitney $U$ was used to identify the differences between genders. The difference between the upper limit of normal for ALT/ALP and the findings of patients were analyzed with the Wilcoxon test. A significance level of $p<0.05$ was accepted.

\section{RESULTS}

The ratio of male patients admitted to the hospital and diagnosed with COVID-19 was higher than female patients (male: $58.280 \%$, female: $41.3 \%$ ) (Table 1). No statistical difference was found between the parameters measured by gender (Table 2). R-factor $\geq 5$ was found to be higher in women than in men. However, it was observed that patients concentrated in the $\mathrm{R} \leq 2$ group (Figure 1). R-values were significantly associated with ALT and ALP. A correlation was detected between ALP and ALT. Also, correlations were observed in both raw R-values and grouped R-Factor values with ALT and ALP (Table 3). It was determined that 256 patients in ALT values were examined without gender reference and 236 patients in ALP values

Table 1: Descriptive statistical findings of parameters measured in patients

\begin{tabular}{lccccc}
\hline & Gender & $\mathbf{n}$ & Mean & Std. D & SEM \\
\hline \multirow{2}{*}{ Age } & Male & 183 & 51.37 & 24.84 & 1.84 \\
& Female & 131 & 47.03 & 26.60 & 2.32 \\
ALT & Male & 183 & 110.23 & 261.71 & 19.35 \\
& Female & 131 & 153.33 & 261.12 & 22.81 \\
ALP & Male & 183 & 259.32 & 307.37 & 22.72 \\
& Female & 131 & 228.31 & 184.79 & 16.15 \\
R-formula & Male & 183 & 2.05 & 5.92 & 0.44 \\
& Female & 131 & 2.77 & 5.00 & 0.44 \\
R-group & Male & 183 & 1.30 & 0.57 & 0.04 \\
& Female & 131 & 1.40 & 0.68 & 0.06 \\
\hline
\end{tabular}

a) $\mathrm{R} \leq 2$ (Total 230)

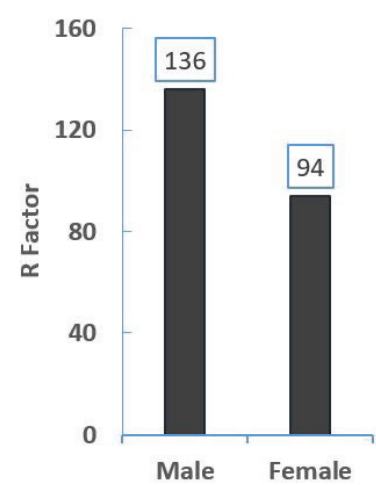

b) R > 2 and 5 (Total 60)

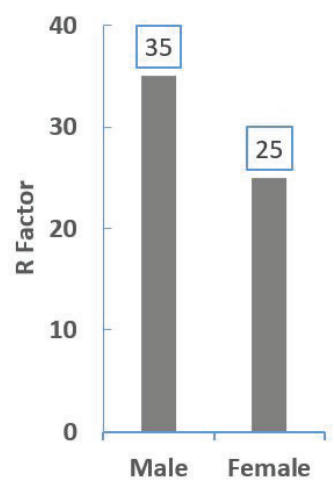

c) $R \geq 5$ (Total 24)

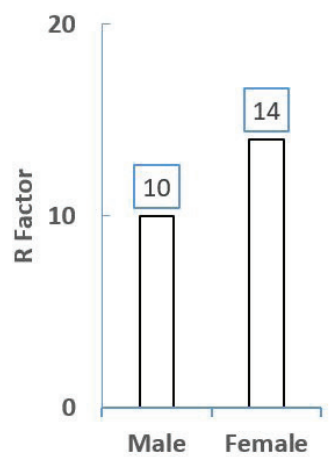

Figure 1: The figure shows the R-ratio groups and numbers determined according to the gender of the patients. R-factor $\geq 5$ was found to be higher in women than in men. However, patients were mostly in $\mathrm{R} \leq 2$ group.

a) R-Factor $\leq 2$ suggests a cholestatic pattern of liver injury and sepsis (male: $74.3 \%$; female: $71.7 \%$ ); b) R-Factor between 2 and 5 suggests a mixed pattern of liver injury (male: 19.12\%; female: $19.08 \%$ ); c) R-Factor $\geq 5$ suggests hepatocellular pattern of liver injury (male: $5.46 \%$; female: $10.68 \%$ ) 
Table 2: Comparison of genders in measured parameters

\begin{tabular}{lccccc}
\hline Test & Age (years) & ALP & ALT & R-formula & R-group \\
\hline Mann-Whitney U & 10727 & 11826 & 10924.5 & 10612 & 11245.5 \\
$\mathbf{Z}$ & -1.588 & -0.202 & -1.339 & -1.733 & -1.206 \\
$\mathbf{P}$ & 0.112 & 0.84 & 0.181 & 0.083 & 0.228 \\
\hline
\end{tabular}

Table 3: Total correlation findings detected in ALP, ALP and R-factor $(n=314)$

\begin{tabular}{lcccc}
\hline Parameters & Age (years) & ALT & ALP & R-formula \\
\hline \multirow{2}{*}{ ALT } & -0.087 & & & \\
& 0.122 & & & \\
ALP & 314 & & & \\
& -0.002 & $.206^{*}$ & & \\
R-formula & 0.969 & 0.000 & & \\
& 314 & 314 & $-.481^{*}$ & \\
& -0.085 & $.687^{*}$ & 0.000 & $.774^{*}$ \\
R-group & 0.132 & 0.000 & 314 & 0.000 \\
& 314 & 314 & $-.193^{*}$ & 314 \\
\hline
\end{tabular}

${ }^{\star}$ Correlation is significant at the 0.01 level (2-tailed).

Table 4: Comparison with the maximum reference value of ALP and ALT Wilcoxon

\begin{tabular}{llcccc}
\hline Parameters & Ranks & $\mathbf{n}$ & Mean rank & Sum of ranks & p \\
\hline & Negative ranks & 51 & 39.07 & 1992.50 & \\
ALT < ALT Max Ref. (35 U/L) & Positive ranks & 256 & 177.41 & 45593.50 & 0.000 \\
& Ties & 7 & & & \\
& Total & 314 & & & \\
& Negative ranks & 78 & 61.30 & 4781.50 & \\
ALP < ALP Max Ref. (120 U/L) & Positive ranks & 236 & 189.29 & 44673.50 & 0.000 \\
& Ties & 0 & & & \\
& Total & 314 & & & \\
\hline
\end{tabular}

were above the accepted maximum normal reference value and both parameters were statistically significant $(p=0.000)$ compared to the upper limit of the accepted reference range $(A L T=35 \mathrm{U} / \mathrm{L}, \mathrm{ALP}=120 \mathrm{U} / \mathrm{L})$ (Table 4).

\section{DISCUSSION}

No significant difference was detected in AST, ALT and R-values by gender in our study. However, the ratio of male patients was higher than female patients. When the literature on the subject is examined, it is seen that men are generally infected more with the virus (16). Moreover a high mortality rate has been commonly reported in males (17). The fact that the male population has more socio-economic mobility than the female population and that they are present more frequently in public areas as well as having high rates of smoking brings along the disease risk. Given their immunocompromised status, more intense surveillance or individually adapted therapeutic approaches are required for severe patients with COVID-19 without gender discrimination.

The present study shows that the new type of coronavirus has an important effect on liver damage. The study also determined that the patients were predominantly in the first group $(R \leq 2)$ for the grouping made according to the 
R-ratio. The finding determined here is also supported by the literature. In a study which was conducted on a cohort of 228 patients, SARS-CoV-2 infection produced acute liver injury in $43 \%$ of chronic liver damage (CLD) patients without cirrhosis. Additionally, $20 \%$ of compensated cirrhosis patients developed either acute-on-chronic liver failure (ACLF) or acute decompensation. Liver-related complications were seen in nearly half of the decompensated cirrhotics, which were of greater severity and with higher mortality (18).

Other studies have also reported clinical features and laboratory test results associated with liver dysfunction in patients with COVID-19 infection $(19,20)$. Pre-existing liver conditions were not listed in most of these studies and the interaction of pre-existing liver disease with COVID-19 was not investigated, which are major limitations in evaluating the underlying causes of liver injury in the course of this severe disease. However, elevated levels of alanine aminotransferase and reduced platelet counts as well as reduced levels of albumin showed an association with higher fatality in COVID-19 patients (21). It is still unknown whether these laboratory analyses are an indicator of pre-existing hepatic diseases in severe patients, or whether they rather mirror liver failure caused by the SARS-CoV-2 itself (22). It is stated in the literature that patients in this group may have sepsis, choledocholithiasis and heart failure (9-12). Since the virus is new, we see that there is little research on the subject. However the literature supports the fact that there are liver problems in COVID-19 patients (7). However, Barrasa et al. found that 48 patients with COVID-19, who completed a 7-day ICU stay, had heart and blood pressure problems in their mortality assessment (23). These findings support the findings determined in the R-ratios in the presented study.

Cai $Q$ et al. investigated the characteristics of liver tests in COVID-19 (24). They reviewed 417 COVID-19 patients with a definitive diagnosis by retrospectively screening clinical records and laboratory results. According to their findings, 318 (76.3\%) of 417 patients had abnormal liver test results. They also found that the presence of abnormal liver tests became more pronounced during hospitalization, and liver enzyme levels increased more than three times after hospitalization. They interpreted their findings as follows: Patients with abnormal liver tests have a higher risk of COVID-19 progressing into a serious disease, so liver damage should be monitored and assessed frequently. Considering that there is a serious elevation in liver enzymes in the findings obtained in our study, it can be said that both studies overlap in this respect.

Another issue that we would like to discuss in our study is the suitability of using the R-ratio monitoring in COVID-19, with treatment still being in the trial phase. Undoubtedly, the fact that the R-ratio was established by the WHO for the distinction of drug-induced acute liver damage enabled it to be used as a criterion for many studies on active ingredients $(9,25)$. According to the findings, the R-ratio defines the liver injury pattern with cholestatic or mixed causes as hepatocellular damage. It is also a value calculated at the onset of liver injury.

According to the results of our study, it is considered appropriate to use the R-ratio for this disease since its treatment protocols are not clear yet, given the effect of COVID-19 disease on the R-ratio. In our opinion, the R-ratio remains reliable for many new pharmaceutical agents. Our recommendation for using the R-ratio for liver damage detection by drug treatments for COVID-19 patients is not just based on our results. Although our study is still the first in the literature, it is also stated elsewhere that the R-criteria are the gold standard in clinical studies that also include the liver. For example, Watkins reported in his "idiosyncratic drug-induced liver injury" study that while the R-ratio provides the best balance of sensitivity and specificity, new composite algorithms provide additional specificity in predicting final development (26). Whritenour $\mathrm{J}$ et al. recommended a lymphocyte transformation test (LTT) for drug-induced liver injury. According to them, this test can be used as a diagnostic method to determine whether a subject with a hypersensitivity reaction has become sensitive to a particular drug (27). In our opinion, although using the R-ratio is regarded as appropriate for drugs used in COVID-19 treatment, it is also possible to evaluate this along with the LTT test. Considering the relationship between the cellular response to the SARS-CoV-2 virus and the immune system, perhaps the R-ratio and LTT test should be used together to distinguish this condition from liver damage.

\section{Limitation of the study}

The relationship between COVID-19 and liver damage was analyzed in a gender reference in this study. Since these patients were not followed up, it is not known if they had previous liver disease. This situation constitutes an important limitation of the study because some studies demonstrated that COVID-19 patients with pre-existing liver disease are at higher risk for hospitalizations and mortality (28-30). Therefore, the impact of pre-existing liver disease on treatment and clinical outcomes of COVID-19 should be determined. Large-scale clinical studies are needed to identify the causes of liver injury in patients with COVID-19 infection.

\section{CONCLUSION}

The R-ratio was examined for the first time in COVID-19 patients in this study. According to the current data, the ALT and ALP values measured in the first blood serum of the patients who were diagnosed with COVID-19 were much higher than normal. This situation showed us the possibility of the SARS-CoV-2 virus causing acute liver 
damage. Indeed, the fact that the R-ratio was found as $<2$ in most of our patients supported this view. Thus, it was thought that monitoring the R-value for COVID-19 could be a guiding parameter for clinicians, particularly in terms of acute liver injury. However, the inability to obtain parameters such as morbidity, mortality, length of hospital stay, intubation, or dialysis data shows the limitation of the study. Therefore, more research is needed to examine the relationship between the R-ratio and COVID-19.

Peer Review: Externally peer-reviewed.

Ethics Committee Approval: This study was approved by the Ethical Committee of the Sakarya University, Faculty of Medicine (Date:13.04.2020, No: 147).

Author Contributions: Conception/Design of Study- H.Y.; Data Acquisition-M.Ö.; Data Analysis/Interpretation- Y.K.; Drafting Manuscript- Y.K.; Critical Revision of Manuscript- H.K., M.Ö.; Final Approval and Accountability- Y.K., H.K., M.Ö.

Conflict of Interest: Authors declared no conflict of interest.

Financial Disclosure: Authors declared no financial support.

\section{Hakem Değerlendirmesi: Dış bağımsız.}

Etik Komite Onayı: Bu çalışma için etik komite onayı Sakarya Üniversitesi, Tıp Fakültesi Etik Kurulu'ndan alınmıştır (Tarih:13.04.2020, Sayı: 147).

Yazar Katkıları: Çalışma Konsepti/Tasarım- H.Y.; Veri ToplamaM.Ö.; Veri Analizi/Yorumlama- Y.K.; Yazı Taslağı- Y.K.; İçeriğin Eleştirel İncelemesi- H.K., M.Ö.; Son Onay ve Sorumluluk- Y.K., H.K., M.Ö.

Çıkar Çatışması: Yazarlar çıkar çatışması beyan etmemişlerdir.

Finansal Destek: Yazarlar finansal destek beyan etmemişlerdir.

\section{REFERENCES}

1. Wang $Y$, Chen J, Chen $Y, W u \quad X T$. Improvement of nonalcoholic fatty liver disease in ALT at $>/=12$ months after Roux-en-Y gastric bypass and sleeve gastrectomy, no effect in ALT and AST at $<12$ months after SG and in AST at $>12$ and $</=24$ months after RYGB. Surg Obes Relat Dis 2020;16(3):447-50. [CrossRef]

2. Moss DW, Henderson RA. Clinical Enzymology In: Burtis CA, Ashwood ER, eds Tietz textbook of clinical chemistry Philadelphia: WB Saunders Company, 1999; 676-84.

3. Friedman L. S, Chopra S, Travis A. C. Approach to the patient with abnormal liver biochemical and function tests. Up to Date, 2014.

4. Yao WH, Wei XL, Guo H, Cheng D, Li H, Sun LM, et al. Tributyltin reduces bone mineral density by reprograming bone marrow mesenchymal stem cells in rat. Environ Toxicol Phar 2020;73:103271. [CrossRef]
5. Thomas L. Alkaline phosphatase (ALP) In: Thomas L, ed Clinical laboratory diagnostics Use and assessment of clinical laboratory results Frankfurt/Main: TH-Books Verlagsgesellschaft, 1998:36-46.

6. Qian ZP, Mei X, Zhang YY, Zou Y, Zhang ZG, Zhu H, et al. Analysis of baseline liver biochemical parameters in 324 cases with novel coronavirus pneumonia in Shanghai area. Zhonghua Gan Zang Bing Za Zhi 2020;28(3):229-33.

7. Zhang C, Shi L, Wang FS. Liver injury in COVID-19: management and challenges. Lancet Gastroenterol Hepatol 2020:5(5):428-30. [CrossRef]

8. Han Y, Zhang H, Mu S, Wei W, Jin C, Tong C, et al. Lactate dehydrogenase, an independent risk factor of severe COVID-19 patients: a retrospective and observational study. Aging (Albany NY) 2020;12(12):11245-58. [CrossRef]

9. Zimmerman HJ, Ishak KG. General aspects of drug-induced liver disease. Gastroenterol Clin North Am 1995;24(4):73957. [CrossRef]

10. Norris W, Paredes AH, Lewis JH. Drug-induced liver injury in 2007. Curr Opin Gastroenterol 2008;24(3):287-97. [CrossRef]

11. Andrade RJ, Lucena MI, Kaplowitz N, Garcia-Munoz B, Borraz Y, Pachkoria K, et al. Outcome of acute idiosyncratic druginduced liver injury: Long-term follow-up in a hepatotoxicity registry. Hepatology 2006:44(6):1581-88. [CrossRef]

12. Wroblewski F, Ladue JS. Serum glutamic pyruvic transaminase in cardiac with hepatic disease. Proc Soc Exp Biol Med 1956:91(4):569-71. [CrossRef]

13. Bergmeyer HU, Horder M. International federation of clinical chemistry. Scientific committee. Expert panel on enzymes. IFCC document stage 2, draft 1; 1979-11-19 with a view to an IFCC recommendation. IFCC methods for the measurement of catalytic concentration of enzymes. Part 3. IFCC method for alanine aminotransferase. J Clin Chem Clin Biochem 1980:18(8):521-34.

14. Bowers GN, Jr., McComb RB. Measurement of total alkaline phosphatase activity in human serum. Clin Chem 1975:21(13):1988-95. [CrossRef]

15. Tietz NW. Textbook of Clinical Chemistry, W.B. Saunders, (ed). 1986.

16. Du RH, Liang LR, Yang CQ, Wang W, Cao TZ, Li M, et al. Predictors of Mortality for Patients with COVID-19 Pneumonia Caused by SARS-CoV-2: A Prospective Cohort Study. Eur Respir J 2020;55(5):2000524. [CrossRef]

17. Liu $Y$, Du $X$, Chen J, Jin $Y$, Peng $L$, Wang HHX, et al. Neutrophil-to-lymphocyte ratio as an independent risk factor for mortality in hospitalized patients with COVID-19. J Infect 2020;81(1):30208-5. [CrossRef]

18. Sarin SK, Choudhury A, Lau GK, Zheng MH, Ji D, AbdElsalam $\mathrm{S}$, et al. Pre-existing liver disease is associated with poor outcome in patients with SARS CoV2 infection; The APCOLIS Study (APASL COVID-19 Liver Injury Spectrum Study). Hepatol Int 2020;14(5):690-700. [CrossRef]

19. Cai Q, Huang D, Yu H, Zhu Z, Xia Z, Su Y, et al. COVID-19: Abnormal liver function tests. J Hepatol 2020;73(3):566-74. [CrossRef]

20. Zhao $X-Y, X u X-X$, Yin H-S, Hu Q-M, Xiong T, Tang Y-Y, et al. Clinical characteristics of patients with 2019 coronavirus disease in a non-Wuhan area of Hubei Province, China: a retrospective study. BMC Infect Dis 2020;20:311. [CrossRef] 
21. Zhou F, Yu T, Du R, Fan G, Liu Y, Liu Z, et al. Clinical course and risk factors for mortality of adult inpatients with COVID-19 in Wuhan, China: a retrospective cohort study. Lancet 2020;395:1054-62. [CrossRef]

22. Boettler T, Newsome PN, Mondelli MU, Maticic M, Cordero $E$, Cornberg $M$, et al. Care of patients with liver disease during the COVID-19 pandemic: EASL-ESCMID position paper. JHEP Rep 2020;2(3):100113. [CrossRef]

23. Barrasa H, Rello J, Tejada S, Martín A, Balziskueta G, Vinuesa C, et al. COVID19 Study Investigators SARSCov-2 in Spanish Intensive Care: Early Experience with 15-day Survival in Vitoria. Anaesth Crit Care Pain Med 2020;39(5):553-61. [CrossRef]

24. Cai Q, Huang D, Yu H, Zhu Z, Xia Z, Su Y, et al. Characteristics of Liver Tests in COVID-19 Patients. J Hepatol 2020;73(3):56674. [CrossRef]

25. Navarro VJ, Senior JR. Drug-related hepatotoxicity. N Engl J Med 2006;354(7):731-39. [CrossRef]
26. Watkins PB. Idiosyncratic drug-induced liver injury in patients: Detection, severity assessment and, regulatory implications. Adv Pharmacol 2019;85:165-93. [CrossRef]

27. Whritenour J, Ko M, Zong Q, Wang J, Tartaro K, Schneider $\mathrm{P}$, et al. Development of a modified lymphocyte transformation test for diagnosing drug-induced liver injury associated with an adaptive immune response. J Immunotoxicol 2017;14(1):31-8 [CrossRef]

28. Singh S, Khan A. Clinical characteristics and outcomes of coronavirus disease 2019 among patients with preexisting liver disease in the United States: a multicenter research network study. Gastroenterology 2020;159(2):768-71. [CrossRef]

29. Gao YD, Ding M, Dong X, Zhang JJ, Kursat Azkur A, Azkur $D$, et al. Risk factors for severe and critically ill COVID-19 patients: A review. Allergy 2021;76(2):428-55. [CrossRef]

30. Ali N. Relationship Between COVID-19 Infection and Liver Injury: A Review of Recent Data. Front Med-Lausanne 2020, 7. [CrossRef] 